\title{
Ethnoclassification, Ethnoecology and the Imagination
}

\section{Peter D. Dwyer}

Translator. Margaret Duhnam

\section{OpenEdition \\ Journals}

\section{Electronic version}

URL: http://journals.openedition.org/jso/321

DOI: $10.4000 /$ jso.321

ISSN: 1760-7256

\section{Publisher}

Société des océanistes

\section{Printed version}

Date of publication: 1 December 2005

Number of pages: 11-25

ISSN: 0300-953x

\section{Electronic reference}

Peter D. Dwyer, "Ethnoclassification, Ethnoecology and the Imagination », Journal de la Société des Océanistes [Online], 120-121 | Année 2005, Online since 27 November 2008, connection on 22 April 2019. URL : http://journals.openedition.org/jso/321 ; DOI : 10.4000/jso.321 


\section{Ethnoclassification, Ethnoecology and the Imagination}

par

Peter D. DWYER*

\section{RÉSUMÉ**}

Deux trajectoires de pensée en ethnoclassification, l'une associée à l'approche de Brent Berlin, l'autre à l'approche de Ralph Bulmer, ont influencé les développements, respectivement en anthropologie cognitive (y compris en psychologie évolutionniste) et en ethnoécologie. La première approche est traitée brièvement. La deuxième est ici explorée plus en détail. Le but de l'ethnoécologie est de comprendre et d'expliquer l'écologie en tant qu'expérience vécue et, en finale, le projet devrait révéler la diversité de l'expérience écologique humaine. Il est soutenu que l'imagination est un élément fondamental de ces expériences. Dans le cadre de cette argumentation, un modèle de l'origine de l'imagination - de la capacité et des implications de l'expression figurative-est proposé.

MoTS-CLÉS : anthropologie cognitive, ethnoclassification, ethnoécologie, imagination, abduction, évolution humaine.

\begin{abstract}
Two trajectories of thought within ethnoclassification, one associated with the approach of Brent Berlin, the other with the approach of Ralph Bulmer, have influenced developments within cognitive anthropology (including evolutionary psychology) and ethnoecology respectively. The former is treated briefly. The latter is explored in greater detail. The aim of ethnoecology is to understand and explain ecology as experienced and, ultimately, the project should reveal the diversity of human ecological experience. It is argued that the imagination is fundamental to those experiences. Within the frame of that argument a model of the origin of the imagination - of the capacity for and implications of figurative expression - is proposed.
\end{abstract}

KEYwORDS: cognitive anthropology, ethnoclassification, ethnoecology, imagination, abduction, human evolution.

Really new concepts, having no names in current language, always make their earliest appearance in metaphorical statements; therefore the beginning of any theoretical structure is inevitably marked by fantastic inventions.

(Langer, 1957: x-xi)

Each and every object in the world has its own history, it goes without saying, which is a result of some other history, and so on; forever continuing. It can be triggered, Ellen was told, by a name. And the unexpected can appear in small and large lumps.

(Bail, 1998: 109)

* School of Anthropology, Geography and Environmental Studies, The University of Melbourne, Victoria, Australia 3010 , pddwyer@unimelb.edu.au.

** Traduction du résumé en français par Margaret Duhnam (LACITO). 
In this article I sketch a trajectory from ethnoclassification to ethnoecology. My emphasis will be with theoretical perspectives and not with ethnographic particulars. I shall argue that the imagination should be understood as fundamental to the project of ethnoecology.

Within the broad field of ethnoclassification, as this developed through the 1960s, 1970s and 1980s, I first identify two trajectories that have, respectively, influenced developments within cognitive anthropology and evolutionary psychology on the one hand and ethnoecology on the other. I briefly critique the former and note the contribution of interest in traditional ecological knowledge to development of the latter. I then direct attention to recent contributions by Ingold (2000) and, with reference to the work of Bateson $(1972,1979)$, seek to expand the former's theoretical perspective by prioritizing the role of the imagination as underlying the relational world that is the proper subject matter of ethnoecological enquiry. From a relational perspective, and as Ingold (1997) has argued, the ecological and social lives of actors, human or otherwise, must be understood as mutually constituted or, as Minnegal (1996) expressed it, «a necessary unity». I use the term " ethnoecology $\gg$ in reference to ecology as experienced and in contrast to "scientific ecology » where the latter may be understood as ecology as analysed. The perspectives implied are those that, in an earlier terminology, were referred to as emic and etic respectively (Pike, 1954: 8; Harris, 1968: 568604; see also Rappaport, 1968: 237-41, on cognized and operational models). The article should be understood as an opinion piece and not as a review.

\section{Ethnoclassification}

Early approaches to ethnoclassification particularly ethnozoology and ethnobotany were concerned with a search for order, or pattern, in the ways in which " other people » name and categorize the living worlds that they experience (e.g. Conklin, 1969). This was my point of entry into the field, indeed into anthropology, in the early 1970s. I entered as a zoologist - ecology was my speciality - with some interest in questions of origin and classification (e.g. Dwyer, 1971). At that time two themes predominated, two theoretically motivated lines of enquiry.

The first of these themes was itself twofold. A concern with cross-cultural regularities in the hierarchical ordering of categories, with taxonomy. And a concern with cross-cultural regularities in the conceptual content of low-ranked categories within those taxonomies; with the extent to which people all over the world recognise the same discontinuities in the natural world, particularly at the level of something analogous to "species ». The contributions of Berlin, Bulmer, their colleagues and their intellectual descendants were of great importance here (e.g. Berlin et al., 1966, 1973; Berlin, 1992; Bulmer and Menzies, 1972, 1973; Bulmer et al., 1975; Ellen, 1975; Hays, 1979; Hunn, 1977).

The second theme was a concern with language universals, with cross-cultural regularities in both the conceptual content and the temporal appearance of higher order categories - Berlin's « life forms » or Bulmer's «primary taxa »within local taxonomies. Here, the contributions of Brown and his colleagues were very influential (e.g. Brown, 1979, 1984, 1986; Brown and Witkowski, 1982).

I identify two primary trajectories of thought in these areas of scholarship. The first takes us rather directly to questions of cognition and, to varying degrees, the domain of theory now known as evolutionary psychology. The second takes us less directly to ethnoecology and, I shall suggest, promises an understanding of the relationship between mind and nature which is different to that offered by evolutionary psychology. My sympathies - my biases - are with this second trajectory. To some extent these two trajectories are informed by differences of approach taken by what I shall call the Berlin school on the one hand and the Bulmer school on the other.

Before tracing out those trajectories I shall reflect critically on the work of ethnotaxonomy. I refer here to the many papers and monographs which have presented other people's classifications of animals and plants as taxonomic hierarchies. My general concern with nearly all this work, including my own (e.g. Dwyer, 1976), is that the representations of other people's understandings were, in the final analysis, grounded in, and deeply prejudiced by, our understandings. What was presented as « their » taxonomy was, ultimately, the closest match that could be found to « our » taxonomy. This was achieved by selective use of data and by devising overarching, metaclassifications that prioritized « western » or « scientific » understandings. (See Ellen, 1993, who elaborated many of the matters I raise in this and the following section.)

For example, many ethnoscientists, especially those who lived for an extended period in the field and were doing other anthropological research in addition to ethnoclassification, understood that the people they lived with car- 
ved up the world in a number of cross-cutting ways. In different contexts and for different purposes those people grouped things in different ways. They operated with multiple classifications of nature. These, of course, confounded scientific aims and expectations. They disrupted the search for generality. The difficulty was resolved by resorting to a classification of classifications, by distinguishing « special purpose classifications 》 from «general purpose classifications » (e.g. Berlin et al., 1966). The former might deal with dietary, medicinal or ritual concerns and so forth. The latter always dealt with morphology and linguistic order and, thus, always emerged, for the people analysed, as the closest approximation to the kind of taxonomies favoured by scientists. But, of course, this approach was inherently arrogant. The « generality » of general purpose classifications was only in the minds of the analysts. It could be most easily elicited in a very «special» context of formal question and answer interviews that were divorced from the ways in which people experienced nature, in which they « lived » with their classifications. It was highly improbable, I suggest, that a general purpose classification elicited by an analyst was any more than another special purpose classification to the people concerned.

If we turn to questions about discontinuities in nature, about « species » and language universals - questions about cross-cultural regularities in the conceptual content of lower and higher order categories - then I have similar concerns. We were offered answers that were too tight, too formal, too enthusiastic in their search for panhuman generalities. The truths revealed were partial. They were never experiential. They were, again, divorced from the life-worlds of the people who were studied.

Perhaps this might be seen most clearly in work on life-forms as language universals. The model for this work was, surely, earlier studies of colour universals (Berlin and Kay, 1969; see also Shepard, 1992, Davidoff et al., 1999). But, here, of course, shared physiology and the laws of physics were implicated in ways that could never apply to the diverse permutations of people and wildlife existing in the real world of ecological interaction. Certainly, all these studies have offered insight into ways in which processes of human classification may be constrained or expressed. I am less confident that they have revealed truths about the lived experience of people.

In summary, an unfortunate consequence of these studies was to objectify systems of knowledge and to render invisible the human actors who build, experience, use and modify those systems. Despite the cautionary remarks of some workers, classical approaches to ethnoclassification turned away from the truths that people are embedded within local environments and that knowledge of the natural world arises through their engagement with those environments (cf. Ellen, 1993; Ingold, 1992). In short, classical approaches sacrificed the relational foundations and ecological embeddedness of all knowledge in favour of devising formal schemes divorced from human agency.

\section{Trajectories: Berlin versus Bulmer}

I turn now to differences in the approaches of the Bulmer and Berlin schools. These differences, I suggest, are implicated in the trajectories of thought leading to ethnoecology on the one hand and evolutionary psychology on the other. The central difference, as I interpret it, is reflected in the fact that the principles Bulmer used to organize data were looser, less formal, and ultimately less constraining of thought, than those used by Berlin.

Thus, Bulmer represented the rank of taxa as primary, secondary, tertiary and so forth and, in so doing, provided opportunities for other people's taxa to "speak in their own right », to fall where they would into an hierarchical structure (Bulmer, 1970). Berlin, by contrast, represented the rank of taxa as unique beginner, life form, generic, specific and varietal and, thereafter, was constrained to provide awkward, and often shifting, definitions of those categories (Berlin et al., 1973; see also Brown, 1987) and to force other people's taxa to conform to those definitions.

Again, when exploring the question of crosscultural regularities in the recognition of discontinuities in nature, Bulmer proposed the notion of specieme - a group of « creatures marked off from all other animals... by multiple distinctions of appearance, habitat, and behaviour »; a notion that was independent of, and unconstrained by, his own system for assigning rank within a taxonomic hierarchy (Bulmer and Tyler, 1968: 372-3). Berlin, by contrast, conflated the possible existence of a fundamental discontinuity in nature with his own imposed system of ordering taxa hierarchically. Berlin's « genera » were both conceptually fixed ranks within a taxonomy and the most probable candidates for giving expression to recognised discontinuities in nature (Berlin, 1973).

In effect, Berlin proposed a universal model designed to accommodate all data; a model, into 
which each analyst was expected to fit his or her data. Bulmer proposed a scheme that encouraged further exploration of data; data which were, so often, less than tidy. The word "tidy" is important here. A set of data organized within the frame of Berlin's principles nearly always appeared more coherent than a set of data organized within the frame of Bulmer's suggestions. It appeared more coherent because it had been accommodated within a fixed framework rather than interpreted in the light of one that was inherently fluid. Perhaps that was a disadvantage of Bulmer's approach? There were, however, significant advantages. I shall return to those. First, however, I shall say something of the move to evolutionary psychology.

\section{Towards Evolutionary Psychology}

The lessons that seemed to emerge from the work of Berlin, Brown and colleagues - the American school - concerned universals of categorization and of the conceptual content of some of those categories. The lessons concerned pattern recognition. They appeared instructive in relation to human cognition (e.g. Atran, 1990; Boster, 1996). The connection to the developing field of evolutionary psychology is strikingly evident in recent work by Atran who wrote:

«Humans everywhere think about plants and animals in highly structured ways. People have similar folk-biological taxonomies composed of essencebased, species-like groups and the ranking of species into lower- and higher-order groups... This supports a modular view of folk-biology as a core domain of human knowledge and as a special player, or "core meme", in the selection process by which cultures evolve. ${ }^{1} \gg(1998: 547)$

I have three difficulties with these understandings. First, with reference to declared universals of taxonomic structure and conceptual content, I assert, as did a number of commentators on Atran's article (e.g. Hays, 1998; MacLaury, 1998; Morton, 1998; Thompson, 1998), that folk taxonomies are more messy than Atran implied $^{2}$. Secondly, with reference to memes, core or otherwise, I assert that theories of universal Darwinism are unlikely to reveal answers to questions about the origin of the imagination and, hence, the evolution of cultural forms. At base, as argued below, this is because the imagination arises within an extra-genetic domain of fluid and facultative response, a developmental domain which cannot be reduced to an orderly combination of high fidelity, high fecundity replicators and non-Lamarckian transmission between individuals (cf. Odling-Smee, 1995; Saunders, 1998) ${ }^{3}$.

And, thirdly, with reference to " modularity » I assert that Atran's approach, indeed the approach of evolutionary psychology in general, is an instance of a mode of explanation, usually flawed, which qualifies as homuncular thinking. Examples of this mode of thought include early representations of genotype for geneticists, deep structures for Lévi-Straussians, innate grammar for Chomskians, habitus for practice theorists and modules of the mind for evolutionary psychologists. In each case the analyst is confronted by an array of facts, of appearances in the world, and seeks to explain them - in a sense to explain them away - by locating an essence of those

1. The epidemiological approach to cognitive anthropology developed by Sperber $(1985,1996)$ is theoretically less constrained than the approach of Atran. Like the latter, however, it is informed by a methodology that prioritizes analytical concerns over experiential concerns and, as evident in Bloch and Sperber (2002), may rely upon hypothesized states (e.g. « attractiveness » and " catchiness ») which are difficult to establish within an empirical frame.

2. See, for example, studies by Tambiah (1969) and Waddy (1982) where higher categories of proposed folk taxonomies are organized around ecological rather than morphological criteria. Note also the methodological sleight-of-hand entailed in assigning taxa, which folk assert to be unplaced within a hierarchical structure, a quasi-formal status as « unaffiliated taxa ». Reports by Clark (1981), Dwyer and Hyndman (1983) and Bulmer (1985) challenge conventional understandings of a fixed array of possible «life form» taxa and Sillitoe (1980, 2002; see also Ellen, 1993: 220-221) has consistently highlighted inconsistency and confusion in folk classifications.

3. Waddington (1960: 94-96; see also 1969) wrote: « Biological evolution... is carried out by an "evolutionary system" which involves four major factors...: a genetic system, which engenders new variation by the process of mutation and transmits it by chromosomal genes; an epigenetic system, which translates the information in the fertilized egg and that which impinges on it from the environment into the character of the reproducing adult; an exploitative system, by which an animal chooses and modifies the environment to which it will submit itself; and a system of natural selective pressures, originating from the environment and operating on the combined result of the other three systems ». Odling-Smee (1995) drew on these understandings to direct attention to mechanisms of inheritance that are extragenetic; that arise, in effect, within the epigenetic and exploitative systems recognised by Waddington (see also Laland, 1992). He argued that the products of development, learning and culture arise from facultative responses and, further, that those products influence the future course of evolution. He considered that his model accommodated « ecological inheritance» in addition to "genetic inheritance ». From a different perspective Gray (1997: 393) argued that «all phenotypes are constructed, not transmitted » and «must develop through organism-environment transactions ». 
appearances within the interior of the form which manifests them, and to then re-read that imagined essence as the mechanism which translates the inside to the outside. The internalized essence of that which is external is an homunculus. Thus, in its earliest representations, before DNA was discovered and unravelled, the genotype was the imagined and mathematically justified essence of the phenotype. The genotype was pure, the phenotype a flawed image (cf. Griffiths, 2002). In a similar way habitus, as a postulated set of embodied dispositions, represents the essence of a social world which is manifest, externally, as practice (e.g. Bourdieu, 1998: 77)4

And so it is, I suggest, with modules of the mind and core memes. Patterns which seem to connect ways of classifying, ways of thinking, in the external world are reduced to essence, objectified as internal mechanisms, as fixed modules, and then turned back to explain the external phenomena from which they were analytically derived. In homuncular thinking externalities, appearances, are taken as epiphenomena. The task is to locate and extol their essence. The advantage of this mode of thinking is that awkward variation may be treated as aberration. The disadvantage is that appearances and variation may be the truths by which people live. And it is this possibility that will take me in the direction of ethnoecology. First, however, I should say something about TEK - traditional ecological knowledge (cf. Ellen et al., 2000).

\section{A Digression on TEK}

During the early 1980s there was an active debate about the underlying purpose of folk biological classifications. Did they primarily serve intellectual or utilitarian ends, a mix of both or neither (e.g. Berlin and Berlin, 1983; Hays, 1982; Hunn, 1982; see also Brown, 1985; Lévi-Strauss, 1966)?

All sides of the debate were impressed by the fact that systems of naming and classifying the natural world revealed that people have extensive and intimate knowledge of their experienced world. The utilitarian argument promoted the view that knowledge was « adaptive »; that there was a close relationship between people's knowledge of the natural world and the ways in which they lived in that world. Systems of naming and of classifying came to be seen as part and parcel of environment-specific survival strategies of different language groups. In turn, this understanding underpinned a growing interest in what became known as « traditional ecological knowledge » or TEK (e.g. Clarke, 1990; Johannes, 1981; Morauta et al., 1982; Posey and Balée, 1989; Williams and Baines, 1993). Studies made under the banner of TEK became divorced from a primary concern with systems of naming and classifying plants and animals and increasingly emphasized relationships - usually functional relationships - between people and wildlife. To the extent that «knowledge» was understood to index those relationships so too it was sometimes regarded as extractable, as a potential commodity.

Perhaps paradoxically, TEK enthusiasts included scholars with adaptationist and evolutionary leanings and others who were not enchanted by these seemingly determinist notions from biology. TEK enthusiasts were often activists, though activists of very different sorts (cf. Dwyer, 1994). With an explicit or implicit appeal to Rousseau some argued that we could learn much, especially about conservation, from « the wisdom of the elders » (e.g. Knudtson and Suzuki, 1992). With a concern for disadvantaged or oppressed peoples, others extolled traditional ecological knowledge - the fruits of the forest as a potential route to cultural survival through participation in a global market (e.g. Clay 1992; cf. Cox and Elmqvist, 1993). And with more nuanced appreciation of both anthropological scholarship, and the hazards of eco-colonialism, others moved TEK into well theorized considerations of intellectual property and the rights that might adhere to this (e.g. Brosius, 1997; Brunois, 1999; Escobar, 1998; Kirsch, 2001; Strathern, 1999).

The rise of TEK achieved two things. First, it animated interest in, and often provided a substantive data base for, studies made under the rubrics of both development and political ecology (e.g. Little, 1999; Paarup-Laursen and Krogh, 2003; Purcell, 1998; Sillitoe, 1998, 2002). Secondly, it redirected attention from names and classifications that had been disembedded from

4. By analogy with the word abduction (« reaching out »; see Peirce [1950a,b] and note 6) the mode of reasoning entailed in homuncular thinking might be labeled adduction « reaching toward»). Thus, adduction is implicated when thinkers postulate the existence of what is essentially imaginary to explain away an awkward gap between two supposedly connected sets of facts. The products of adduction are of homuncular form. They recreate an essence of one domain of facts and locate it within the «body» of the other set of facts as a mechanism which supposedly translates from one to the other. Abduction deals in processes that connect; adduction deals in essentialized states that connect. Abduction reaches out to the world; adduction reaches in to the centre. 
local contexts in the course of analysis to peopleenvironment relations that were sometimes encoded in those names and classifications and were sometimes expressed in other ways, perhaps simply in the course of a person's engagement with environment, with land and with other people. This refocus of attention was also significant in the development of ethnoecology.

\section{Towards Ethnoecology}

To me there is one body of theoretical writing which stands out in pointing the way to what I regard as ethnoecology. This is the work that Ingold has published through the past ten years. Much of this is included in his recent collection The Perception of the Environment: Essays on Livelihood, Dwelling and Skill (2000). The related work of, particularly, Bird-David, Descola, Hornborg and Pálsson is also important to the development of ethnoecology (e.g. Bird-David, 1990, 1993, 1999; Descola, 1994; Descola and Pálsson, 1996; Hornborg, 1998; see also Roepstorff et al., 2003). What Ingold offers is a substantive and internally consistent body of writing that both engages with other theoretical positions while sketching a program for future research and understanding. But, I shall argue later, that program, as Ingold develops it, contains a weakness, a lacuna.

Ingold's work did not emerge from a specific interest in human knowledge systems. Rather, his concern was to dissolve the dualities that so insistently separated biophysical from sociocultural understandings of people and, indeed, separated the practitioners of those viewpoints. He sought to articulate a vision of the whole such that organisms (or persons) « grew » within fields of relationships that were themselves established through the participation of those organisms in particular local environments. Here Ingold borrowed from, and brought together, an « ecological» critique of mainstream cognitive psychology and a "developmentalist » critique of mainstream neo-Darwinian biology (e.g. Gibson, 1979; Goodwin, 1994). Within the frame of that synthesis the human being was to be understood « as a single locus of creative growth within a continually unfolding field of relationships » (Ingold, 2000: 5-6).

In his essays on "livelihood», Ingold addressed issues of subsistence procurement with particular reference to hunter-gatherer societies. By arguing that ways of « acting in the environment are always ways of perceiving » that environment, he sought to dispose of the artificial separation between practicallygrounded subsistence and imaginativelygrounded cosmology (Ingold, 2000: 9). He offered, instead, an appreciation of the importance of engagement with the human and non-human constituents of their environment in grounding the knowledge that each person has of, and brings to bear on, that environment.

In his essays on "dwelling » Ingold challenged the view, as he saw it, that people construct the world, or attach meaning to it, prior to acting in it; the view that naive subjects enter a pregiven world. Rather, he argued that it is through engagement with an experienced world that the world itself comes into being around the organism (or person) and, similarly, that the constituents of that world «take on significance through their incorporation into a regular pattern of life activity » (Ingold, 2000: 153). Engagement with the world, meanings attached to the world and the world as experienced are indivisibly connected and simultaneously created. In the development of this argument, Ingold's essay on globes and spheres is particularly instructive in contrasting the lived experiences of inhabitants of so-called modern and pre-modern worlds (Ingold, 2000: 209-218). The opacity of a globe connotes a separation of society and nature, with humans on the outside, looking in, but, perhaps, seeing little; the transparency of a sphere connotes a unitary experience of a world seen from within.

And, in his third set of essays, Ingold developed and explored the idea that skill is best understood as referring to " the capabilities of action and perception of the whole organic being " which dwells in "a richly structured environment ». Skills, he argued, are as much « biological as cultural», they are not « transmitted from generation to generation but are regrown in each » (Ingold, 2000: 5). As is his wont, Ingold again framed his insights through the strategy of challenging a distinction he judged to be flawed. In this case a distinction between the supposed foundations of art and technology; intellectual "design » or creativity in the first case and mechanical execution in the second. Both, he asserted, may be understood with reference to skill. Both " grow» in and from an on-going process of enskilment - a process that, in the act of engagement, may entail a directing of attention by one practitioner to another rather than the transmission of fixed rules or representations (see also Pálsson, 1994).

Ingold represented his synthesis as drawing together perspectives that are relational, ecologi- 
cal and developmental. There are, perhaps, some difficulties in the way he articulates the social and, more so, appears to marginalize or dismiss the cultural ${ }^{5}$. To me, however, he has offered much of, though not all, the necessary foundations of ethnoecology.

\section{An Ethnographic Interlude}

Since 2001, with colleagues, I have been working with commercial fishers in the Australian state of Victoria. Most may be classed as smallscale, family-oriented fishers; they are life-style fishers.

In the earliest phases of this work we learned the names of many boats. Boats were an important part of the biography of fishers. Often we also learned the origin of the name. Two themes dominated these tales of origin. In the majority of cases names reflected affiliations - to people or to places - that had been created by the person who named the boat. Boats were named after wives and children, after female affines, but rarely after parents or siblings. They were names about self-created past and present relationships in the world. In most of the remaining cases the name of the boat reflected either an imagined quality or an intended purpose of the boat. They were statements about the hopes and aspirations of the namer, about future relationships in the world. These latter names were given by fishers who, at some level, sought to explore the current limits, the margins, of the fishing industry or who were themselves marginal to the industry and the community of "those who fish" (Dwyer et al., 2003).

The naming of boats is, of course, a private act. But a named boat is in the public domain. Gradually we came to appreciate that, through the bestowal of names, and through their associations with many fishers, boats were personalized and themselves developed a biography. Named and personalized boats served to socialize the sea, to recreate on the water the on-shore attachments and connections entailed in the names that those boats carried.

To fishers and their families, named and personalized boats become an embodiment of meanings. But those meanings do not arise de novo, they are not inscribed upon a blank slate. People, surely, engage with environments before they name places, things and beings within them. As Ingold argued, meanings arise from that engagement: people " think the thoughts they do » because they dwell in, and engage with, the world (2000: 186). Names emerge from, and re-present, human-environment relations which have been constituted through that recursive interaction. And, thereafter, they alter the understandings that each person brings to future engagement and the interpretations that all people derive from that engagement. Boats at sea, named and personalized boats, may be readily appreciated as exemplars of the transformation of an unmarked environment into « humanized, historicized space » (Weiner, 1991: 50); as ever-mobile places affording fixed social reference (paraphrased from Dwyer et al., 2003: 20).

And that creative - that human-achievement, I assert, may be understood only in a context of an on-going engagement, of an on-going relationship, between people and environment. A dialectical relationship which I take to be central to the study of ethnoecology.

\section{The Primal Trope and the Imagination}

I suggested earlier that a set of taxonomic data organized within a Bulmerian frame might appear less tidy than a set organized within a Berlinian frame. I suggested also that this seeming disadvantage might, in fact, be turned to advantage.

But why is Bulmer's organizational scheme less tidy than that of Berlin? I think for a very simple reason. A reason that is, perhaps, most transparent in his seminal paper "Why is the

5. Some commentators misinterpret Ingold as allowing no space for the social when, in fact, his dual concerns, as I understand them, are to deny existence of, first, a social domain that is uniquely human and, secondly, a neat dichotomy of relationships between persons and « others » into those that are social and those that are not. Ingold has been also criticized for adopting an extreme position in denying that non-Western people's distinguish between, for example, the « biological processes of reproduction and the social processes of nurture » (Astuti, 2000: 430-431; cf. Minnegal and Dwyer, in press). My concerns are different. Ingold's style of argument is internally consistent, coherent and free of ambiguity or tautology. Sometimes, however, in disposing of the dualities which pattern so much scholarly discourse he appears to attribute these same qualities (of consistency, coherence, etc.) to the non-Western people of whom he writes. But a lack of internal consistency and much ambiguity may be common and necessary features of most human systems; they may facilitate both communication between components of those systems and expressions of agency by their participants. By way of illustration, despite the logical contradictions identified by Ingold (2000: 132-151), both engagement with environment and a commitment to ancestry may have often featured as parallel discourses in constructions concerning ownership and use rights to land by indigenous peoples and, in different circumstances, empowered those people to act to their own advantage on the basis of one or the other discourse (see, for example, Dwyer and Minnegal, 1999). 
cassowary not a bird? » (1967) but is evident, as well, in related explorations of the question of anomaly (1978, 1979, 1986). Here he engaged with the work of scholars such as Douglas (1970, 1973) and Tambiah (1969) whose contributions to the understanding of animal classification were not beholden to the developing methodological frame of ethnoscience and whose work held little salience to most American ethnoscientists. Those contributions, of course, concerned symbols and symbolization. And Bulmer's contributions to the organization of ethnoclassificatory data appear less tidy than Berlin's for the simple reason that he was an anthropologist of such broad persuasion. " Man and a Half » is the appropriate lead title of the collection of essays that honour his scholarship (Pawley, 1991). An " academic bricoleur» he once wrote of himself. A bricoleur who might « take this piece of super-structure from Lévi-Strauss, that metaphorical connecting link from Mary Douglas ", and so on, as required by the questions he addressed (Bulmer, 1974: 94).

$\mathrm{He}$ was too modest. Bulmer's writings in ethnoscience were always and insistently contextualized within an overarching and broad appreciation of generic anthropological concerns. To read "Why is the cassowary not a bird? " is to understand that questions of ethnoclassification may be never divorced from those of symbolization. It was Bulmer's writings that, in the first instance, challenged my zoological imagination and led me to confront issues of metaphor, of tropes, of polarity and analogy, of objectivity and subjectivity and, eventually, to re-discover the relational foundations of ecology as experienced (Dwyer, 1979, 1986, 1996).

Implicit in much early ethnoscientific work is an assumption that the mental process underlying the classification of nature is one of dividing or separating out the world. This is implicit in much of the work of Lévi-Strauss (e.g. 1966). It is true, of course, that the taxonomies which result from this process prioritize separations, divisions, oppositions. They prioritize polarity.
The taxonomies are products of a classifying process. In the « here and now » polarity structures those products. It is easy to assume, therefore, that the process by which those taxonomies were generated was itself grounded in polarization, in opposing one part of the world to some other part to construct contrasting taxa of different content or contrasting totems with different referents.

I do not agree with this understanding of the classificatory process. Process has been confounded with product. My preferred position prioritizes analogy as fundamental to the process of classification and polarity as fundamental to the products - the taxonomies - that result. Humans detect similarities between things in the world. Through their engagement with the world things are brought into conjunction. In the imagination those things appear as related, as being in some sense like one another. The relationship is metaphoric but may be concretized, it is perhaps given a label, a name (Dwyer, 1979). And, henceforth, that imagined relationship is established in the mind as a thing that contrasts with all other things in the world. In this sense, then, taxonomies are, in the first instance, the unintended product of a process of metaphorization or, more precisely, of abduction ${ }^{6}$.

Let me travel back to the beginning - to $a$ beginning - and speculate about the origin of the imagination. A leap of the imagination for me. A leap into the imagination for the first humans ${ }^{7}$.

Imagine a pre-human being, engaged with environment in much the same way that Ingold might write of engagement. Caught up in a myriad relations with others, both animate and inanimate (Fig. 1a). Not all the relationships which could exist in the world but a sample. A sample biased by the dictates of survival and reproduction within a specific local environment. A creature embedded in relationships, reacting to and acting upon those relationships, relationships that are grounded in exploration, social facilitation, memory, imitation, learning (in all its forms), instruction and

6. Abduction is the basis of a mode of explanation, distinct from causal or functional, that takes the following form: accept hypothesis $\mathrm{X}$ as true if, by so doing, the (surprising) observation $\mathrm{A}$, or set of observations $\mathrm{A} \ldots \mathrm{n}$, is a matter of course. For example: the facts A... $\mathrm{n}$ (clues) are a matter of course if person $\mathrm{X}$ was the murderer: therefore, accept the hypothesis that $\mathrm{X}$ was the murderer. Or, again: the fit of reproducing and variable organisms to their environments (set of observations each of which carries the name « adaptation ») is a matter of course if context-dependent differential survival and reproduction (hypothesis that carries the name « natural selection ») is true; therefore, accept the hypothesis of natural selection (cf. Peirce, 1950a, 1950b; see also Bateson, 1979; Bateson and Bateson, 1987; Harries-Jones 1995). The products of abduction - « hypotheses » about the world - are persuasive and take hold to the extent that others declare, as at the end of a good detective story, or on reading The Origin of Species, « what a fool I was not to see that ». Bateson (1979: 142) considered that « metaphor, dream, parable, allegory, the whole of art, the whole of science, the whole of religion, the whole of poetry, totemism » are all « instances or aggregates of instances of abduction, within the human mental sphere ».

7. What follows is an expanded version of a summary paragraph in Dwyer (1996: 179). 
(a) prehuman

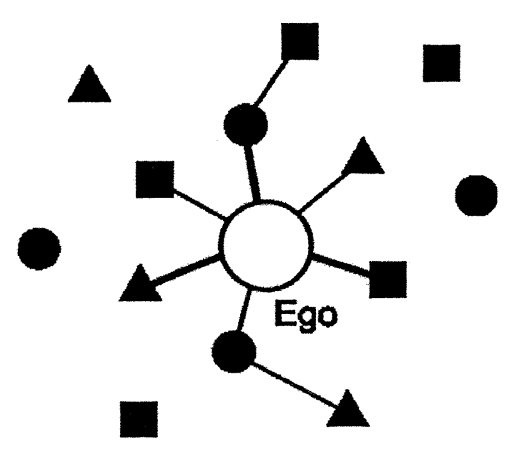

(b) protohuman

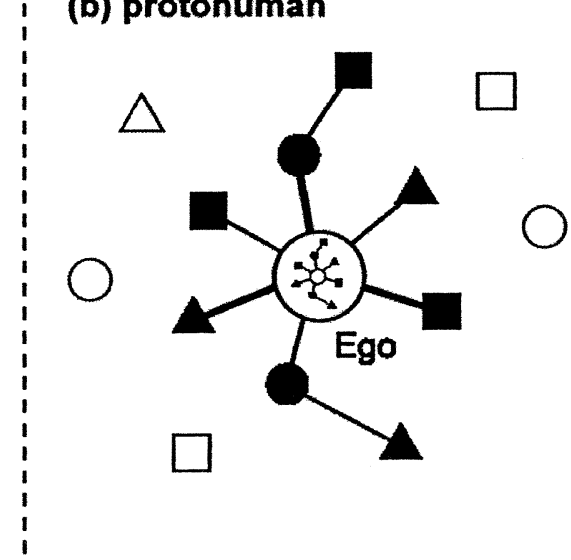

FIGURE 1. - (a) A representation of the world of prehuman. A focal prehuman, Ego, is embedded at a given moment in a set of socio-ecological relationships with some, but not all, others and objects (circles, triangles and squares) in the world. On the figure, lines vary in thickness to reflect variation in the intensity or functional importance of particular relationships. (b) A representation of the world of protohuman. Compare with $<a>$. Here the set of socio-ecological relationships within which Ego is embedded is re-presented in Ego's brain as an homuncular image of self. Others and objects that are not party to those relationships (now shown as open symbols) do not contribute to that image and, hence, from the outset, it is, but is not $<$ known $>$ to be, a biased reflection of all that exists.

familiarity. My creature experiences the world but does not yet imagine it. My creature is not self-aware ${ }^{8}$.

But now imagine the shift to self-awareness. What could that be? How might we construct that within the terms of reference of the lived experience of pre-human? We have no basis for suggesting that a capacity for self-awareness is implanted: that a mutation arises, that God speaks. And if that is correct then, in the first instance, self-awareness can be neither more nor less than an internalization of all the relationships of which pre-human was a part; relationships which had arisen in the context of engagement with environment and which patterned that engagement in the present and into the future (Fig. 1b). Self-awareness can be no more than an internalization of that which was exter- nal. There was nothing else to grasp. In its origins self-awareness is a trope, the first trope, the primal trope ${ }^{9}$. A leap into the imagination. An error of judgement in which the outside is taken to be the inside ${ }^{10}$.

That then is the primal trope. A familiar world of relationships taken to metaphorize an unfamiliar sense of self, contradiction embodied in an emergent notion of self and the world both re-presented as and reduced to the statistical mean of all extant configurations of relationships. Simultaneously an instance of metaphor, irony, synecdoche and metonymy. The primal trope emerged from the experienced world, was relational in form and genetically uncommitted ${ }^{11}$.

But so much more is contained within this notion. The primal trope was Machiavellian, a

8. There are huge definitional problems with regard to all matters concerning consciousness and mind, human or otherwise. I use the word « imagination » to refer to the creative faculty that is underlain by abduction. Its products are images that have no material existence. It is contingent upon (and coincident with) emergence of a capacity for self-reflexion that is a necessary precursor to self-awareness. Although, in this article, I write of «self-awareness » I do not intend an abrupt transition but, rather, a temporal continuum that is initiated by emergence of a capacity for self-reflexion. In a similar way my preference is to distinguish "sentience ", as a capacity for feeling that is evident in many plants and animals, from « consciousness ", as an awareness of feeling that is evident in, at least, many animals.

9. The word « trope » is a generic, a higher level category, for figures of speech - for metaphor, metonymy, simile, irony, pun and so forth - though I extend that dictionary meaning to include, not just figurative language, but all figurative expression. Gesture is important, and ritual or art that are not or cannot be put into words are undoubtedly important. It is tropes that inform the resemblances humans detect between things, the relationships they infer from those things, the classificatory order they impose upon things, and the contrasts they detect and express as differences between things; in short, the meanings they derive from or attach to things. "The four major tropes of metaphor, metonymy, synechdoche, and irony, are cognitive examples, respectively, of perspective, reduction, representation, and dialectic » (Parkin, 1982: xxvii).

10. The primal trope may be understood as well as the first instance in human affairs of a process of disembedding (cf. Hornborg, 1996); a process, which, with its connotation of objectification, is usually treated as a correlate, attribute, or outcome of modern society.

11. In this article I do not take a position with respect to either a necessary connection between tropes (cf. symbols) and language (cf. Wagner,1972; Fernandez, 1991) or the temporal conjunction of the origins of self-awareness (cf. human « consciousness ») and language. Many writers assert or argue for a primal association between these human characteristics 
self-deceiving image of self as the template upon which both rhetoric and objectivity were to be nurtured. A figurative beginning that would implode as literal. It was, quite literally, a graven image, hewn in or on the brain, and represented there as a diffuse array of always malleable processes and structures built by and recursively building the complex analogical relations that were its source. As the initial expression of selfawareness, the primal trope was the substrate upon which purposeful action and social life were patterned. In as much as that trope was necessarily fluid, shifting in expression as humans altered their relationships with others and environments, so also it conditioned ever-changing perspectives on the world and ever-changing patterns of engagement with the world ${ }^{12}$.

And, of course, this sketch of the primal trope aligns me firmly with Bateson's understanding that mind and nature are a necessary unity (1979). It offers a perspective on cognition that is not beholden to environments of evolutionary adaptation or to imagined homunculi of the mind. A perspective in which abduction is the foundation of both the imagination and thought and the source of all creativity ${ }^{13}$.

The primal trope returns me also to the possibility of an enlarged perspective on ethnoecology.

\section{The Scope of Ethnoecology}

I am impressed by Ingold's recent writings on livelihood, dwelling and skill. Those writings provide a solid base from which to develop an understanding of ways in which other people experience ecology, of ways in which they engage with, and built upon, the ecological relationships of which they are a part. A solid base from which to develop an informed ethnoecology. An ecology that reaches beyond commitment to an analytical separation of organism and environment. An ecology that acknowledges, with Waddington (1960: 94), that an animal « by its behaviour contributes in a most important way to determining the nature and intensity of the selective pressures which will be exerted on it $»$. Or to understanding, with Rappaport (1990: 69) that ecosystems are « part of the world's means for maintaining, if not indeed constructing ecosystems». And with Uexküll (1982) that organisms lived in their own subjective worlds and that ecological relations are semiotic.

But I have two difficulties with Ingold's position. First, he disparages evolutionary thinking more than is warranted. This complaint derives, perhaps, from my training in and sympathies for

(e.g. Knight et al., 1995; Dennett, 1996; Deacon, 1997). I am not convinced that an intimate association in the present establishes or requires a simultaneity of origins.

12. Three problems must be considered. First, I describe the primal trope as being an internalization of that which was external and, thus, may be guilty of flawed homuncular thinking? If I am wrong about the primal trope then I am guilty. But if I am correct then the protohumans, of whom I write, are innocent. They do not seek to explain appearances away but, rather, are now equipped with, even burdened by, a means of reaching out via on-going abduction to the world of appearances and into the world of explanations. They are now creative beings, henceforth unaware that the source of their creativity was an image of the relationships within which they participated and which they now sought to explain. The second problem concerns the way in which (the mechanism by which) the primal trope spreads through a population of protohumans. This is a general problem. It recurs in all evolutionary accounts concerning the survival, spread and eventual dominance of « hopeful monsters ». I briefly addressed it above by proposing that an outcome of self-awareness was to re-present and reduce the world « to the statistical mean of all extant configurations of relationships ». This is not enough. I might argue that to the extent that the primal trope conditions present and future engagement for ego so ego's relationships with others will condition their present and future engagement. I might build on this suggestion by drawing from Sperber's epidemiological model $(1985,1996)$ of the spread of representations. That model, of course, is at base a genetically uncommitted Darwinian model in which the prime mover of change at the level of populations is selection. The third problem concerns the fact that by proposing a « primal trope »I have reified a set of relations that cannot be - or should not be - reified. This is a difficult and interesting problem. To assign a name is to reify a relation. There are no trees, there are only particular trees, the taxon «tree " reifies our fundamentally tropic understanding of a domain of perceived similarities between particular trees. The domain is specified by a set of relations and is objectified by assigning a name. For analysts who seek to prioritize relations (processes) relative to entities (products) there is a huge problem here. The analyst cannot proceed without imposing categories, which at some level must be arbitrary, on the material to be analysed; he or she cannot proceed - cannot speak, cannot write - without seeming to reduce relations to objects. I have decided to live with the demon of reductionism on an understanding that in a world of multiple relationships, " things » are both inevitable and necessary because only with individuated « things » (actual or imagined) can the ambiguity inherent in those relationships be reduced (cf. Wilden, 1972, on the role of abstract digital constructions in communication).

13. In a recent unpublished paper Godelier (2002) wrote: «The imaginary is not the symbolic, even though the two are inseparable. The imaginary consists of shared ideas and beliefs whose meaning is expressed in signs and symbols. The imaginary is therefore not simply thought. It is symbolically inscribed in the body, in the things that humans make, in monuments, in the organization of space and time. But the stated aim of these imaginary constructions and symbolic practices is not only imaginary or not only symbolic. [...] The imaginary and the symbolic [...] have real social consequences which are not all in the mind. [...] If one must ascribe a primacy to one of these three dimensions, all of which are real, it should clearly go to the imaginary and not to the symbolic. Symbols die once they have lost their meaning, not only the meaning from which they sprang, but all the meanings they have accrued to them in the course of their existence. « The imaginary, however, is forever. 
scientific biology ${ }^{14}$. For present purposes, it is less important than the second difficulty.

Ingold fails to allow a place for metaphor. At base the engagement of which he writes exists in a material world of ecological relationships and the persons he constructs are similarly grounded. That they are grounded is important for, in this, he avoids appeal to explanation based in imagined homunculi. But to me, at its source, through its on-going expression, and in its potential, human engagement with the world, and the persons unfolding through that engagement, are always and necessarily grounded in metaphor, in tropes, in the imagination. Without this understanding there is a risk, a risk implied by my quotations from Waddington, Rappaport and Uexküll, that Ingold has identified the subjective experience which distinguishes the living from the non-living but has failed to mark out that domain of the living which qualifies as human.

In my own imaginings, therefore, I seek an ethnoecology which combines the substantive understandings of Ingold with the often elusive temptations of Bateson. An ethnoecology that, in drawing from both environmental engagement and social understandings, no longer needs to ask « which came first? » or posit polarities and causal arrows that have no salience in the developmental trajectories of so many people (cf. Bamford, 1998). An ethnoecology which acknowledges that perceptions of the environment are grounded in tropes, that the environment as experienced emerges from this ground, and that the imaginary cannot be divorced from livelihood, dwelling and skill. An ethnoecology in which personhood, sociality and the imagination " grow » in contexts that people themselves abductively create. An ethnoecology which, like Bulmer's scheme for organizing classificatory data, is theoretically open-ended, that allows that in different times and places people experience and understand their relations to environment in very different ways. An ethnoecology which recognises that, as analysts, we ourselves may only imagine those different ways if we accept that they are always outcomes of the play of the imagination of others.
All this is important to the development of ethnoecology. We should not forget that ethnoecology must aim to understand and explain ecology as experienced and that, ultimately, the project should reveal the diversity of human ecological experience. In current approaches there is a tendency to universalize by portraying the experience of some people as the experience of all, to prioritize our interpretations of the experience of those who we judge to be the least disembedded, the experience of those who live in societies where « local and implicit meanings » prevail (Hornborg, 1996: 45). But many people do not live this way. Rather, they live in societies where, through a process of disembedding, those local and implicit meanings have, at least in part, been subordinated to " abstract, totalizing systems $\gg$ and to understandings and practices that, so often, are guided by entrenched polarities (Hornborg, 1996: 45). Here, then, we must accept that it will be these understandings and practices which shape the experience of those people. We must allow that an ethnoecological appreciation of « the west » may be quite unlike that of « the rest ».

Early work in ethnoclassification tended to both model and judge others with reference to an image of ourselves. In ethnoecology we must avoid the inverse temptation to interpret ourselves in their image. We must be careful to neither model nor judge ourselves or our compatriots in terms of understandings drawn from people who engage with worlds of entirely different shape.

\section{Acknowledgements}

Special thanks to Christian Coiffier and Florence Brunois who very generously organized an April 2003 meeting of the Société des Oceanistes at the Musée de l'Homme, Paris, at which I presented an earlier version of this article. Many thanks also to everyone who participated at that meeting, to colleagues and students with whom I have discussed ideas presented in this article, to Monica Minnegal for valued critical comment, and to Florence Brunois and Michel Legrand-

14. Ingold refers to a « colossal misunderstanding » by biologists in the history of their subject. This is the fact that the word « evolution » originally meant, to biologists and others, what the word « development » now means [...] an unfolding (1998; see also 2000). Ingold exploits this largely unacknowledged historical change to prop an argument against the view favoured by most biologists: that the prime mover of " evolutionary » change - of change in form through time and space - is a process of context-dependent differential survival and reproduction (i.e. a process of natural selection) that is ultimately expressed through shifts in the representation of " genes » in populations. He refers to the explanatory poverty of neo-Darwinian theory and argues that developmental and not genetic mechanisms are primary in promoting change. He overstates his case. Darwinian selection - but not necessarily « genes » - is always implicated in the reproduction of form in changing contexts. And, further, many biologists consider that selection is not the only process implicated in evolution. While sympathetic to Ingold's intentions with respect to a more generic understanding of evolutionary process I consider that he promotes a unitary vision when multiple processes, including selection (and, often, selection operating at a genetic level) are almost certainly implicated. 
Borderune for exceptional hospitality in France. My anthropological research over many years has been facilitated by The University of Queensland, the University of Melbourne, the Papua New Guinea Biological Foundation, the Australian Research Council and by many Papua New Guinean Siane, Etolo, Kubo and Bedamuni people and Victorian fishers.

\section{BIBLIOGRAPHY}

Astuti Rita, 2000. Are we all natural dualists? A cognitive developmental approach, Journal of the Royal Anthropological Institute (N.S.) 7, pp. 429447.

Atran Scott, 1990. Cognitive Foundations of Natural History: Towards an Anthropology of Science, Cambridge, Cambridge University Press.

-, 1998. Folk biology and the anthropology of science : Cognitive universals and cultural particulars, Behavioral and Brain Sciences 21, pp. 547-609.

BAIL Murray, 1998. Eucalyptus, Melbourne, Text Publishing.

BAMFord Sandra, 1998. Humanized landscapes, embodied worlds: Land and the construction of intergenerational continuity among the Kamea of Papua New Guinea. Social Analysis 42, pp. 28-54.

BATESON Gregory, 1972. Steps to an Ecology of Mind: Collected Essays in Anthropology, Psychiatry, Evolution and Epistemology, New York, Ballantine Books.

-, 1979. Mind and Nature: A Necessary Unity, New York, E.P. Dutton.

Bateson Gregory and Mary C. BAteson, 1987. Angels Fear: An Investigation into the Nature and Meaning of the Sacred, London, Rider.

BerLin Brent, 1973. Folk systematics in relation to biological classification and nomenclature, Anпиаl Review of Ecology and Systematics 4, pp. 259-271.

-, 1992. Ethnobiological Classification: Principles of Categorization of Plants and Animals in Traditional Societies, Princeton, Princeton University Press.

Berlin Brent and Elois A. BerLin, 1983. Adaptation and ethnozoological classification: Theoretical implications of animal resources and diet of the Aguaruna and Huambisa, in R. B. Hames and W. T. Vickers (eds), Adaptive Responses of Native Amazonians, New York, Academic Press, pp. 301-328.

Berlin Brent, Dennis Breedlove and Peter H. RAVEN, 1966. Folk taxonomies and biological classification, Science 154, pp. 273-275.

-, 1973. General principles of classification and nomenclature in folk biology, American Anthropologist 75, pp. 214-242.
Berlin Brent and Paul Kay, 1969. Basic Color Terms: Their Universality and Evolution, Berkeley, University of California Press.

BIRD-DAVID Nurit, 1990. The giving environment: Another perspective on the economic system of gatherer-hunters, Current Anthropology 31, pp. 189196.

_, 1993. Tribal metaphorization of human-nature relatedness: a comparative analysis, in K. Milton (ed.), Environmentalism: The View from Anthropo$\log y$, London, Routledge, pp. 112-125.

—, 1999. « Animism » revisited: Personhood, environment, and relational epistemology, Current Anthropology 40 , pp. S67-S91.

Bloch Maurice and Dan SPerber, 2002. Kinship and evolved psychological dispositions: The mother's brother controversy reconsidered, Current Anthropology 4, pp. 723-748.

BOSTER James, 1996. Human cognition as a product and agent of evolution, in R. Ellen and K. Fukui (eds), Redefining Nature: Ecology, Culture and Domestication, Oxford, Berg, pp. 269-289.

Bourdieu Pierre, 1998. Practical Reason: On the Theory of Action, Cambridge, Polity Press.

Brosius J. Peter, 1997. Endangered forest, endangered people: Environmentalist representations of indigenous knowledge, Human Ecology 25, pp. 47-69.

Brown Cecil H., 1979. Folk zoological life-forms: Their universality and growth, American Anthropologist 81, pp. 791-817.

_, 1984. Language and Living Things: Uniformities in Folk Classification and Naming, New Brunswick, Rutgers University Press.

-, 1985. Mode of subsistence and folk biological taxonomy, Current Anthropology 26, pp. 43-63.

-, 1986. The growth of ethnobiological nomenclature, Current Anthropology 27, pp. 1-19.

_, 1987. The folk subgenus: A new ethnobiological rank, Journal of Ethnobiology 7, pp. 181-192.

Brown Cecil H. and Stanley R. Witкowski, 1982. Growth and development of folk zoological lifeforms in the Mayan language family, American Ethnologist 9, pp. 97-111.

BRUNOIS Florence, 1999. In paradise, the forest is open and covered in flowers, in C. Kocher Schmid (ed.), Expecting the Day of Wrath: Versions of the Millennium in Papua New Guinea, Boroko, PNG, National Research Institute, pp. 111-130.

BULMER Ralph N. H., 1967. Why is the cassowary not a bird? A problem of zoological taxonomy among the Karam of the New Guinea highlands, Man (N.S.) 2, pp. 5-25.

1970. Which came first, the chicken or the egghead?, in Jean Pouillon et Pierre Maranda (éds), Échanges et communications : mélanges offerts à Claude Lévi-Strauss à l'occasion de son $60^{e}$ anniversaire, Paris, Mouton, pp. 1069-1091. 
—, 1974. Memoirs of a small game hunter: On the track of unknown animal categories in New Guinea, Journal d'agriculture tropicale et de botanique appliquée 21, pp. 79-100.

—, 1978. Totems and taxonomy, in L. R. Hiatt (ed.), Australian Aboriginal Concepts, Canberra, Australian Institute of Aboriginal Studies, pp. 1-19.

—, 1979. Mystical and mundane in Kalam classification of birds, in R. F. Ellen and D. Reason (eds), Classifications in their Social Context, London, Academic Press, pp. 57-79.

—, 1985. Trees, grerbs, wugs, snurms and quammals: The new universal natural history of Cecil $\mathrm{H}$. Brown, Journal of the Polynesian Society 94, pp. 431-437.

—, 1986. The unsolved problems of the birds of Leviticus, Working Paper 73, Department of Anthropology, University of Auckland. $60 \mathrm{p}$.

Bulmer Ralph N. H. and James I. Menzies, 1972. Karam classification of marsupials and rodents Part 1, Journal of the Polynesian Society 81, pp. 472499.

—, 1973. Karam classification of marsupials and rodents - Part 2, Journal of the Polynesian Society 82, pp. 86-107.

Bulmer Ralph N. H. and Fred Parker, 1975. Kalam classification of reptiles and frogs, Journal of the Polynesian Society 84, pp. 267-308.

Bulmer Ralph N. H. and Michael J. Tyler, 1968. Karam classification of frogs, Journal of the Polynesian Society 77, pp. 333-385.

Clark Ross, 1981. Snakes, snails and « life forms », Journal of the Polynesian Society 90, pp. 267-269.

Clarke William C., 1990. Learning from the past: Traditional knowledge and sustainable development, The Contemporary Pacific 2, pp. 233-253.

Clay Jason W., 1992. Buying in the forests: A new program to market sustainably collected tropical forest products protects forests and forest residents, in K. H. Redford and C. Padoch (eds), Conservation of Neotropical Forests: Working from Traditional Resource Use, New York, Columbia University Press, pp. 400-415.

ConkuIN Harold C., 1969. Lexicographical treatment of folk taxonomies, in S. A. Tyler (ed.), Cognitive anthropology, New York, Holt, Rinehart and Winston, pp. 41-59.

Cox Paul A. and Thomas Elmqvist, 1993. Ecocolonialism and indigenous knowledge systems: Village controlled rainforest preserves in Samoa, Pacific Conservation Biology 1, pp . 6-13.

Davidoff Jules, Ian Davies and Debi Roberson, 1999. Colour categories in a stone-age tribe, Nature 398, pp. 203-204.

Deacon Terrence, 1997. The Symbolic Species: The Co-evolution of Language and the Human Brain, London, Penguin Books.
DenNetT Daniel C., 1996. Kinds of Minds: Towards an Understanding of Consciousness, London, Weidenfeld \& Nicholson.

Descola Philippe, 1994. In the Society of Nature: A Native Ecology in Amazonia, Cambridge, Cambridge University Press.

Descola Philippe and Gísli Pálsson (eds), 1996. Nature and Society: Anthropological Perspectives, London, Routledge.

Douglas Mary, 1970. Purity and Danger: An Analysis of Concepts of Pollution and Taboo, Middlesex, Penguin Books.

-, 1973. Natural Symbols, Middlesex, Penguin Books.

DWyer Peter D., 1971. Temperature regulation and cave-dwelling in bats: an evolutionary perspective, Mammalia 35, pp. 424-455.

—, 1976. An analysis of Rofaifo mammal taxonomy, American Ethnologist 3, pp. 425-445.

—, 1979. Animal metaphors: An evolutionary model, Mankind 12, pp. 13-27.

_, 1986. Living with rainforest: The human dimension, in J. Kikkawa and D. J. Anderson (eds), Community Ecology: Pattern and Process, Melbourne, Blackwell Scientific Publications, pp. 342-367.

-, 1994. Modern conservation and indigenous peoples: In search of wisdom, Pacific Conservation Bio$\log y$ 1, pp. 91-97.

_, 1996. The invention of nature, in R. Ellen and K. Fukui (eds), Redefining Nature: Ecology, Culture and Domestication, Oxford, Berg, pp. 157-186.

Dwyer Peter D. and David C. Hyndman, 1983. «Frog » and « lizard »: Additional life-forms from Papua New Guinea, American Anthropologist 85, pp. 890-896.

Dwyer Peter D., Roger Just and Monica Minnegal, 2003. A sea of small names: Fishers and their boats in Victoria, Australia. Anthropological Forum 13, pp. 5-26.

Dwyer Peter D. and Monica Minnegal, 1999. The transformation of use rights: A comparison of two Papua New Guinean societies, Journal of Anthropological Research 55, pp. 361-383.

ELLEN Roy F., 1975. Variable constructs in Nuaulu zoological classification, Social Science Information 14, pp. 201-228.

-, 1993. The Cultural Relations of Classification: An Analysis of Nuaulu Animal Categories from Central Seram, Cambridge, Cambridge University Press.

Ellen Roy F., Peter Parkes and Alan Bicker (eds), 2000. Indigenous Environmental Knowledge and its Transformations: Critical Anthropological Perspectives, Amsterdam, Harwood Academic Publishers.

EsCOBAR Arturo, 1998. Whose knowledge, whose nature? Biodiversity, conservation, and the political ecology of social movements, Journal of Political Ecology 5, pp. 53-82. 
Fernandez James W. (ed.), 1991. Beyond Metaphor: The Theory of Tropes in Anthropology, Stanford, Stanford University Press.

Gibson James J., 1979. The Ecological Approach to Visual Perception, Boston, Houghton Mifflin.

GoDELIER Maurice, 2002 (November 18). Breaking the mirror of the self: "Is social anthropology indissolubly linked to the west, its birthplace? ", Page Barbour Lecture III, University of Virginia (Translated from French by Nora Scott).

Goodwin Brian C. 1994. How the Leopard Changed its Spots: The Evolution of Complexity, London, Weidenfeld \& Nicolson.

Gray Russell, 1997. « In the belly of the monster »: Feminism, developmental systems and evolutionary explanations, in P. A. Gowaty (ed.), Feminism and Evolutionary Biology: Boundaries, Intersections and Frontiers, New York, Chapman and Hall, pp. 385-413.

Griffiths Paul, 2002. Lost: One gene concept. Reward to finder, Biology and Philosophy 17, pp. 271-283.

Harries-Jones Peter, 1995. A Recursive Vision: Ecological Understanding and Gregory Bateson, Toronto University of Toronto Press.

HARris Marvin, 1968. The Rise of Anthropological Theory: A History of Theories of Culture, New York, Thomas Y. Crowell Company.

HAYs Terence E., 1979. Plant classification and nomenclature in Ndumba, Papua New Guinea. Ethnology 18, pp. 253-270.

-, 1982. Utilitarian/adaptationist explanations in folk biological classification: Some cautionary notes, Journal of Ethnobiology 2, pp. 89-94.

—, 1998. Xenophobia and other reasons to wonder about the domain specificity of folk-biological classification, Behavioral and Brain Sciences 21, pp. 575-576.

HornBorg Alf, 1996. Ecology as semiotics: Outlines of a contextualist paradigm for human ecology, in P. Descola and G. Pálsson (eds), Nature and Society: Anthropological Perspectives, London, Routledge, pp. 45-62.

_, 1998. Ecological embeddness and personhood: Have we always been capitalists?, Anthropology Today 14, pp. 3-5.

Hunn Eugene, 1977. Tzeltal Folk Zoology: The Classification of Discontinuities in Nature, New York, Academic Press.

- 1982 . The utilitarian factor in folk biological classification, American Anthropologist 84, pp. 830-847.

INGOLD Tim, 1992. Culture and the perception of the environment, in E. Croll and D. Parkin (eds), Bush Base, Forest Farm: Culture, Environment and Development, London, Routledge, pp. 39-56.

-, 1997. Life beyond the edge of nature? Or, the mirage of society, in J. D. Greenwood (ed.), The Mark of the Social: Discovery or Invention?, Lon- don, Rowman \& Littlefield Publishers, Inc., pp. 231-252.

-, 1998. The evolution of society, in A. C. Fabian (ed.), Evolution: Society, Science and the Universe, Cambridge, Cambridge University Press, pp. 79-99.

- 2000. The Perception of the Environment: Essays in Livelihood, Dwelling and Skill, London, Routledge.

JARA Fabiola, 2002. The meaning of nominal animal categories among the Caribs of the Guiana, Anthropos 97, pp. 117-126.

JOHANNES Robert E., 1981. Words of the Lagoon: Fishing and Marine Lore in the Palau District of Micronesia, Berkeley, University of California Press.

KIRSCH Stuart, 2001. Environmental disaster, «culture loss » and the law, Current Anthropology 42, pp. 167-198.

KNight Chis, Camilla Power and Ian Watts, 1995. The human symbolic revolution: A Darwinian account, Cambridge Archaeological Journal 5, pp. 75-114.

KnUdTson Peter and David T. Suzuki, 1992. Wisdom of the Elders, Sydney, Allen and Unwin.

LALAND Kevin N., 1992. The role of social transmission in evolution, Ethology and Sociobiology 13, pp. 87-113.

LANGer Susanne K., 1957 (3rd edition). Philosophy in a New Key: A Study in the Symbolism of Reason, Rite and Art, Cambridge, M.A., Harvard University Press.

LÉvi-Strauss Claude, 1966. The Savage Mind, London, Weidenfeld and Nicholson.

LitTLE Paul E., 1999. Environments and environmentalisms in anthropological research: Facing a new millennium, Annual Review of Anthropology 28, pp. 253-284.

Maclaury Robert E., 1998. Domain-specificity in folk biology and color categorization: Modularity versus global process, Behavioral and Brain Sciences 21, pp. 582-583.

MinNEGAL Monica, 1996. A necessary unity: the articulation of social and ecological explanations of behaviour, Journal of the Royal Anthropological Institute (N.s.) 2, pp. 141-158.

Minnegal Monica and Peter D. DWyer, (in press). Fertility and social reproduction in the StricklandBosavi region, in S. J. Ulijaszek (ed.), Fertility and Reproduction in New Guinea, Berghahn Books, Oxford.

Morauta Louise, John Pernetta and William HeaNEY (eds), 1982. Traditional Conservation in Papua New Guinea: Implications for Today, Boroko, Papua New Guinea, Institute of Applied Social and Economic Research.

Morton Adam, 1998. What is rank?, Behavioral and Brain Sciences 21, p. 585.

ODLING-SMEE John, 1995. Biological evolution and cultural change, in E. Jones and V. Reynolds (eds.), 
Survival and Religion: Biological Evolution and Cultural Change, New York, John Wiley and Sons, pp. 1-43.

PaArup-Laursen Bjarke and Lars Krogh., 2003. The duality of indigenous environmental knowledge among the Fulani of northern Burkina Faso, in A. Roepstorff, N. Bubandt and K. Kull (eds), Imagining Nature: Practices of Cosmology and Identity, Langelandsgade, Denmark, Aarhus University Press, pp. 204-216.

PÁlsson Gísli, 1994. Enskilment at sea. Man (N.s.) 29, pp. 901-927.

PARKIN David, 1982. Introduction, in D. Parkin (ed.), Semantic Anthropology, New York, Academic Press, pp. xi-li.

Pawley Andrew (ed.), 1991. Man and a Half: Essays in Pacific Anthropology and Ethnobiology in Honour of Ralph Bulmer, Auckland, The Polynesian Society.

PEIRCE Charles S., 1950a. Abduction and induction, in J. Buchler (ed.), The Philosophy of Peirce: Selected Writings, New York, Harcourt, Brace \& Company, pp. $150-156$

_, 1950b. Perceptual judgements, in J. Buchler (ed.), The Philosophy of Peirce: Selected Writings, New York, Harcourt, Brace \& Company, pp. 302-305.

PIKE Kenneth, 1954. Language in Relation to a Unified Theory of the Structure of Human Behavior, vol. 1, Glendale, Summer Institute of Linguistics.

Posey Darrell A. and William BALÉE (eds), 1989. Resource Management in Amazonia: Indigenous and Folk Strategies, New York, The New York Botanical Garden.

Purcell Trevor W., 1998. Indigenous knowledge and applied anthropology: questions of definition and direction, Human Organization 57, pp. 258-272.

RAPPAPORT Roy A., 1968. Pigs for the Ancestors: Ritual in the Ecology of a New Guinea People, New Haven, Yale University Press.

— 1990. Ecosystems, populations and people, in E. F. Moran (ed.), The Ecosystem Approach in Anthropology: From Concept to Practice, Ann Arbor, University of Michigan Press.

Roepstorff Andreas, Nils Bubandt and Kalevi Kull, 2003. Imagining Nature: Practices of Cosmo$\operatorname{logy}$ and Identity, Langelandsgade, Denmark, Aarhus University Press.

SAUNDERS Barbara, 1998. What is empirical about Atran's taxonomies? Behavioral and Brain Sciences 21, pp. 587-588.

SHEPARD Roger N., 1992. The perceptual organization of colors: An adaptation to regularities of the terrestrial world?, in J. H. Barkow, L. Cosmides and J. Tooby (eds), The Adapted Mind: Evolutionary Psy- chology and the Generation of Culture, Oxford, Oxford University Press, pp. 495-532.

Sillitoe Paul, 1980. Confusions in the classifications: How the Wola name their plants, Ethnos 45, pp. 133-156.

_ 1998. The development of indigenous knowledge: A new applied anthropology, Current Anthropology 39 , pp. 223-252.

_, 2002. Contested knowledge, contingent classification: Animals in the highlands of Papua New Guinea, American Anthropologist 104, pp. 1162-1171.

—, 2002. " Maggots in their ears »: Hunting incantations and indigenous knowledge in development, Journal of Ritual Studies 16, pp. 64-77.

SPERBER Dan, 1985. Anthropology and psychology: towards an epidemiology of representationsn Man (N.s.) 20, pp. 73-89.

-, 1996. Explaining Culture: A Naturalistic Approach, Oxford, Blackwell.

Strathern Marilyn, 1999. Property, Substance and Effect: Anthropological Essays on Persons and Things, London, The Athlone Press.

TAmbiah Stanley J., 1969. Animals are good to think and good to prohibit, Ethnology 8, pp. 423-459.

Thompson Michael, 1998. The living individual and its kind, Behavioral and Brain Sciences 21, p. 591.

UEXKüLL Jacob von, 1982 [1940]. The theory of meaning, Semiotica 42, pp. 25-82.

Waddington Conrad H., 1960. The Ethical Animal, London, George Allen and Unwin.

_, 1969. Paradigm for an evolutionary process, in C. H. Waddington (ed.), Towards a Theoretical Biology. 2 : Sketches, Edinburgh, Edinburgh University Press.

WADDY Julie, 1982. Biological classification from a Groote Eylandt Aborigine's point of view, Journal of Ethnobiology 2, pp. 63-77.

WAGNER Roy, 1972. Habu: The Innovation of Meaning in Daribi Religion, Chicago, The University of Chicago Press.

WeINer James F., 1991. The Empty Place: Poetry, Space and Being among the Foi of Papua New Guinea, Bloomington, Indiana University Press.

WILDEN Anthony, 1972. System and Structure: Essays in Communication and Exchange, London, Tavistock Press.

Williams Nancy M. and Graham Baines (eds), 1993. Traditional Ecological Knowledge: Wisdom for Sustainable Development, Canberra, Centre for Resource and Environmental Studies, Australian National University. 
